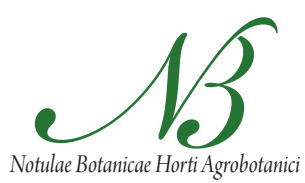

Cluj-Napoca

\title{
Physico-Chemical Characteristics at Three Development Stages in Pomegranate cv. 'Hicaznar'
}

\author{
Sadiye GOZLEKCI ${ }^{1}$, Sezai ERCISLI² ${ }^{2}$, Filiz OKTUREN³, Sahriye SONMEZ ${ }^{3}$ \\ ${ }^{1}$ Akdeniz University, Faculty of Agriculture, Department of Horticulture, 07070 Antalya, Turkey; sgozlekci@akdeniz.edu.tr \\ ${ }^{2}$ Ataturk University, Faculty of Agriculture, Department of Horticulture, 25240 Erzurum, Turkey; sercisli@gmail.com \\ ${ }^{3}$ Akdeniz University, Faculty of Agriculture, Department of Soil Science and Plant Nutrition, 070709 Antalya, Turkey
}

\begin{abstract}
During the last decade consumption of pomegranate (Punica granatum L.) has been highly recommended, based on the presence of phytochemicals with health protective effects for humans. Apart from these compounds, pomegranate might apport high levels of minerals, however, they are likely to be affected by cultivar, environment and development stage of fruits. In this study, some physicochemical characteristics along with minerals $(\mathrm{P}, \mathrm{K}, \mathrm{Ca}, \mathrm{Mg}, \mathrm{Na}, \mathrm{Fe}, \mathrm{Mn}, \mathrm{Zn}$ and $\mathrm{Cu}$ ) were determined in fruits in three development stage (immature, unripe and full ripe) of pomegranate cv. 'Hicaznar' grown in Antalya, Turkey. The most of physico-chemical characteristics and concentrations of minerals of pomegranate strongly influenced by development stage. Fruit weight was $7.25 \mathrm{~g}, 140.57 \mathrm{~g}$ and $423.16 \mathrm{~g}$ in immature, unripe and full ripe stages. 100 aril weight changed from $0.34 \mathrm{~g}$ to $33.21 \mathrm{~g}$ during development stage. Soluble solid content were $6.16 \%, 10.38 \%$ and $15.84 \%$ in immature, unripe and full ripe stages. The contribution to the intake of minerals was in general high, with special emphasis on the contributions of K, Ca and Mn.
\end{abstract}

Keywords: aril, minerals, physico-chemical content, pomegranate

\section{Introduction}

The pomegranate is an ancient fruit with a wealthy history in legend, symbol, art, medicine and religion. It is grown mainly in Mediterranean and Asia countries including Spain, Turkey, Morocco, Egypt, Israel, Tunisia, Saudi Arabia, Azerbaijan, Iran, Pakistan, Afghanistan, India, China. Among these countries, India, Iran, China and Turkey are main producer (El-Nemr et al., 1990; Ercisli et al., 2007).

Pomegranate has been associated with a high nutritional value and a large number of health benefits. It is a good source of antioxidants, vitamins as it includes vitamin A, C and E as well as folic acid. This fruit consists of three times the antioxidants of wine or green tea. It is said to be the powerhouse of health. Pomegranates are known mostly for curing the problems related to heart and for maintaining effective and healthy blood circulation. Other health benefits include cure of stomach disorders, cancer, dental care, osteoarthritis, anaemia and diabetes (ViudaMertos et al., 2010).

Fruits are rich in minerals, which are essential for a wide variety of metabolic and physiologic processes in the human body. Among the nutrients found in fruits, minerals represent a class of inorganic substances that is present in all kinds of fruits. The human body needs about twenty different minerals in order to function properly (Williams, 2006). These elements can be classified into macro and microminerals. Macro minerals are needed in amounts higher than $100 \mathrm{mg}$ /day and include calcium (Ca), phosphorus $(\mathrm{P})$, magnesium $(\mathrm{Mg})$, sulfur $(\mathrm{S})$, sodium $(\mathrm{Na})$, chloride $(\mathrm{Cl})$ and potassium $(\mathrm{K})$. Microminerals (needed in amounts lower than $100 \mathrm{mg} /$ day) include elements such as iron $(\mathrm{Fe})$, zinc $(\mathrm{Zn})$, iodine $(\mathrm{I})$, selenium $(\mathrm{Se})$, manganese $(\mathrm{Mn})$, chromium $(\mathrm{Cr})$, copper $(\mathrm{Cu})$, molybdenum (Mo), fluorine $(\mathrm{F})$, boron (B), cobalt (Co), silicon ( $\mathrm{Si})$, aluminum $(\mathrm{Al})$, arsenic $(\mathrm{Ar})$, tin $(\mathrm{Sn})$, lithium $(\mathrm{Li})$ and nickel (Ni) (Mahan and Escott-Stump, 2005). Fruits are the most important source of both are macro and microminerals (Pellerano et al., 2008), which indispensable for the maintenance of life, growth, and reproduction (Alsafwah et al., 2007). Mineral and trace element intake in humans is directly related to their food habits and the food content.

The physico-chemical characterization of pomegranate samples is important because the physico-chemical composition is closely related to the quality and preservation of products. Pomegranate fruit maturity status is commonly assessed based on external (skin) colour, aril and juice colour and acidity of juice (Cristosto et al., 2000). Similarly, the acceptability of pomegranate to the consumer and processor depends on a combination of several quality attributes that are related to the physico-chemical properties including size, skin color, sugar content, acidity and flavour. Pomegranate fruit is consumed directly as fresh arils as well as fresh juice (Al-Said et al., 2009). 
242

The determination of mineral and trace elements is important nowadays for enhancing production efficiency in agriculture (Hamilton et al., 1998). The importance of appropriate intakes of essential mineral elements for the maintenance of an optimal health state is widely known (Avioli, 1988).

Several authors (Ercisli and Esitken, 2004; Gates and Lehmann, 1968; Kodia et al., 1979) have shown the great variations in nutrient composition among and within the existent species, depending on the nature of soils, the climate, the farming conditions and methods, and the ripening state. Also, the introduction of new varieties and the adoption of modern farming practices in commercial horticulture may modify the concentrations of the different mineral elements in the fruits.

The aim of this study is to determine the influence of the development stage on the physico-chemical fruit properties along with concentration of minerals in pomegranate cv. 'Hicaznar'. We also aimed to estimate the contributions of the consumption of pomegranate to the recommended daily intakes or the estimated daily requirements for these mineral elements.

\section{Material and methods}

The study was conducted in Antalya province in Turkey. The well-known, dominant pomegranate cultivar ' $\mathrm{Hi}$ caznar' was used as material. Fruits were sampled at three development stages: $1^{\text {st }}$ stage; immature fruit (June 15), $2^{\text {nd }}$ stage; unripe fruit (August 15); $3^{\text {rd }}$ stage; full ripe fruit (October 15). The physico-chemical (pomological) analyses encompassed 50 random mature fruits. Moisture (\%), total protein (\%), fruit weight $(\mathrm{g}), 100$ aril weight $(\mathrm{g})$, fruit diameter and length $(\mathrm{mm})$, calyx length $(\mathrm{mm})$, skin thickness $(\mathrm{mm})$, skin and aril color $\left(L^{*}, a^{*}, b^{*}\right.$ and chroma values), $\mathrm{pH}$, titratable acidity (\%) and soluble solid content (\%) were determined. Fruit and 100 aril weight was counted by using a digital balance with a sensitivity of $0.001 \mathrm{~g}$. Linear dimensions, length and diameter and calyx length and skin thickness of fruits were measured by using a digital caliper gauge with a sensitivity of $0.01 \mathrm{~mm}$. Fruit skin color (as $L^{*}, a^{*}, b^{*}$ and chroma values) was measured on the cheek area of 30 fruits (Minolta Chroma Meter CR-400, Minolta-Konica, Japan)

Flesh parts of fruit samples were used to assess the $\mathrm{pH}$, soluble solid content (SSC) and titratable acidity. Soluble solid contents (SSC) were determined by extracting and mixing one drops of juice from the each fruit into a digital refractometer and displayed as \%. Titratable acidity and $\mathrm{pH}$ were determined according to procedure of AOAC (1995). Total protein quantity was calculated by multiplying the nitrogen content by the coefficient 6.25 using Kjeldahl method (AOAC, 1995). Moisture was also determined according to AOAC (1995) procedures. For mineral contents determination, fresh fruit were washed, air-dried and fractionated into the skin, seed, aril and juice and analyzed for mineral content using atomic absorption spectrophotometry (AOAC, 1995). The phosphovanademolybdate method was used for the estimation of phosphorus (AOAC, 1995) while Potassium and Sodium were determined by flame photometry.

The statistical analyses were carried out using SAS (SAS Inst., 2005).

\section{Results and discussions}

Results of proximate physico-chemical characteristics at different development stages of pomegranate cv. 'Hicaznar' are presented in Tab. 1. We found significant differences on all searched parameters between immature, unripe and full ripe stages $(\mathrm{p}<0.05)($ Tab. 1).

Average fruit weight of cv. 'Hicaznar' were $7.25 \mathrm{~g}$, $140.57 \mathrm{~g}$ and $423.16 \mathrm{~g}$ at immature, unripe and full ripe stages, respectively. Al-Maiman and Ahmad (2002) reported similar trends in three development stages in pomegranate. Previous studies pointed that, fruit weight of pomegranate cultivars at full ripe stage was found between 150-568 g (Al-Maiman and Ahmad, 2002; Ercan et al., 1992; Kazankaya et al., 2003; Polat et al., 1995; Tibet and Onur, 1999; Ozkan, 2005; Yildiz et al., 2003; Yilmaz et al., 1992). Our fruit weight at full ripe stage is within these limits. On the other hand, average fruit length and diameter of cv. 'Hicaznar' were determined as $46.85 \mathrm{~mm}, 83.26$ $\mathrm{mm}$ and $106.99 \mathrm{~mm} ; 22.11 \mathrm{~mm}, 66.77 \mathrm{~mm}$ and $95.52 \mathrm{~mm}$ at immature, unripe and full ripe stages, respectively (Tab. 1). Some studies conducted on fruit length and diameter at full ripe stage of pomegranate cultivars ranged from 61 to $91 \mathrm{~mm}$ and 36 to $104 \mathrm{~mm}$ (Al-Maiman and Ahmad, 2002; Kazankaya et al., 2003; Tibet and Onur, 1999; Yilmaz et al., 1992;) which supports our findings.

One hundred aril weight were changed from $0.34 \mathrm{~g}$ at immature stage and increased to $12.11 \mathrm{~g}$ at unripe stage and finally reached $33.21 \mathrm{~g}$ at full ripe stages (Tab. 1). Consumed part of pomegranate is called aril. Ercisli et al., (2007) reported 100 aril weight between 17.19-49.86 $\mathrm{g}$ among pomegranate selections from Turkey. Celik and Ercisli (2009) reported 100 aril weight as 27,60 g in pomegranate cv. 'Eksinar'.

Skin color of pomegranate cv. 'Hicaznar' was determined as $L$ value (lightness) 41.84, 60.01 and $58.71 ; a$ value $34.87,-6.32,32.72$ and $b$ value $28.08,38.19$ and 28.97 at immature, unripe and full ripe stage. Ercisli et al. (2007) determined $L$ value between 41.14 and 73.47; $a$ value -2.73 and 51.82 and $b$ value between 17.47 and 42.46 at full ripe stages in pomegranates .

Aril color of pomegranate cv. 'Hicaznar' was determined as $L$ value (lightness) 36.70, 56.92 and 34.97; $a$ value $21.81,3.18,11.92$ and $b$ value $17.91,12.29$ and 4.09 at immature, unripe and full ripe stage. Ercisli $e t$ al. (2007) determined $L$ value between 20.90 and 44.13, a value between 15.16 and 31.42 and $b$ value between 11.41 and 20.51 at full ripe stage among pomegranate genotypes 
selected from Coruh valley in Turkey. According to these results, $a$ and $b$ values was found to be lower in comparison to previous research. However, it was shown that $L$ values were similar to the previous result (Poyrazoglu et al., 2002).

The arils of pomegranates contain considerable amounts of acids, sugars, vitamins, polysaccharides, polyphenols and important minerals (Al-Maiman and Ahmad, 2002). In present study, soluble solid content (SSC) of cv. 'Hicaznar' at three development stages were 6.16\%, $10.38 \%$ and $15.84 \%$ (Tab. 2). Significant variations in soluble solid content (11-23\%) of pomegranates have been reported over the years by various researchers (Al-Maiman and Ahmad, 2002; Ercan et al., 1992; Kazankaya et al., 2003; Ozkan, 2005; Polat et al., 1999; Tibet and Onur, 1999; Yildiz et al., 2003; Yilmaz et al., 1992).

The moisture content values were $21.14 \%$ at immature stage, $74.85 \%$ at unripe stage and $75.99 \%$ in full ripe stage. The total protein content was highest in the immature stage $(17.71 \%)$ followed by unripe stage $(9.50 \%)$ and decreased to $5.31 \%$ at full ripe stage (Tab. 1). Al-Maiman and Ahmad (2002) reported total protein content in juice and seed of pomegranate as $1.05 \%$ and $4.06 \%$ respectively. However El-Nemr et al. (1992) reported 13.2\% protein in seeds in pomegranate.

Titratable acidity were determined as $1.02 \%$ at immature stage, $3.12 \%$ at unripe stage and $1.73 \%$ at full ripe Tab. 1. Pomological characteristics of pomegranate fruit at different development stages

\begin{tabular}{|c|c|c|c|}
\hline \multirow[b]{2}{*}{ Characteristics } & \multicolumn{3}{|c|}{ Development stages } \\
\hline & $\begin{array}{c}\text { Immature } \\
\text { fruit }\end{array}$ & $\begin{array}{l}\text { Unripe } \\
\text { fruit }\end{array}$ & $\begin{array}{c}\text { Mature } \\
\text { fruit }\end{array}$ \\
\hline Fruit weight (g) & $7.25 c$ & $140.57 \mathrm{~b}$ & $423.16 \mathrm{a}$ \\
\hline 100-Aril weight (g) & $0.34 \mathrm{c}$ & $12.11 \mathrm{~b}$ & $33.21 \mathrm{a}$ \\
\hline Fruit diameter (mm) & $22.11 \mathrm{c}$ & $66.77 \mathrm{~b}$ & $95.52 \mathrm{a}$ \\
\hline Fruit lenght (mm) & $46.85 \mathrm{c}$ & $83.26 \mathrm{~b}$ & $106.99 a$ \\
\hline Calyx lenght (mm) & $22.32 \mathrm{c}$ & $23.96 b$ & $24.50 \mathrm{a}$ \\
\hline Skin thickness (mm) & $5.16 \mathrm{a}$ & $4.51 \mathrm{~b}$ & $4.22 \mathrm{~b}$ \\
\hline \multicolumn{4}{|l|}{ Skin color } \\
\hline$L^{*}$ (ligthness) & $41.84 b$ & $60.01 \mathrm{a}$ & $58.71 \mathrm{a}$ \\
\hline$a^{*}$ & $34.87 \mathrm{a}$ & $-6.32 c$ & $32.72 b$ \\
\hline$b^{*}$ & $28.08 \mathrm{~b}$ & $38.19 \mathrm{a}$ & $28.97 b$ \\
\hline Chroma & $44.77 \mathrm{a}$ & $38.71 \mathrm{~b}$ & $43.70 \mathrm{a}$ \\
\hline \multicolumn{4}{|l|}{ Aril color } \\
\hline$L^{*}$ (ligthness) & $36.70 \mathrm{~b}$ & $56.92 \mathrm{a}$ & $34.97 \mathrm{c}$ \\
\hline a & $21.81 \mathrm{a}$ & $3.18 \mathrm{c}$ & $11.92 \mathrm{~b}$ \\
\hline$b^{*}$ & $17.91 \mathrm{a}$ & $12.29 b$ & $4.09 c$ \\
\hline Chroma & $28.09 \mathrm{a}$ & $12.69 \mathrm{~b}$ & $12.60 \mathrm{~b}$ \\
\hline Moisture (\%) aril & $21.14 b$ & $74.85 \mathrm{a}$ & $75.99 \mathrm{a}$ \\
\hline Total protein (\%) aril & $17.71 \mathrm{a}$ & $9.50 \mathrm{~b}$ & $5.31 \mathrm{c}$ \\
\hline $\mathrm{pH}$ & $4.56 a$ & $2.95 \mathrm{c}$ & $3.17 \mathrm{~b}$ \\
\hline Titratable acidity (\%) & $1.02 \mathrm{c}$ & $3.12 \mathrm{a}$ & $1.73 b$ \\
\hline Soluble solid content (\%) & $6.16 c$ & $10.38 \mathrm{~b}$ & $15.84 \mathrm{a}$ \\
\hline
\end{tabular}

Values in the same line with different letters are significantly at $\mathrm{P}<0.05$. NS: Non significant stage, respectively (Tab. 1). According to titratable acidity values, cv. 'Hicaznar' can be clasified as sweet sourish (12\%) at full ripe stages (Onur and Kaska, 1985).

Tab. 2 shows the results of mineral contents of the skin, aril, seed and juice of cv. 'Hicaznar' at immature, unripe and full ripe development stages. Significant statistical differences were recovered $(p<0.05)$ among development stages on minerals except $\mathrm{P}, \mathrm{K}$ and $\mathrm{Na}$ for skin (Tab. 2).

The skin and aril was found to contain all searched minerals at both unripe and full mature stages. In immature stages, we did not obtain enough material to determine minerals because there were no juice and seeds at this stage.

Considering skin of cv. 'Hicaznar' fruit, $\mathrm{P}$ was the highest in skins at unripe development stage (0.33\%). K was the equal amount both immature and unripe stage (1.22\%). Ca and Fe were the highest at full mature stage $(0.34 \%$ and $28.07 \mathrm{ppm})$ and $\mathrm{Mg}, \mathrm{Mn}, \mathrm{Zn}$ and $\mathrm{Cu}$ were the highest at immature stage $(0.08 \%, 31.33 \mathrm{ppm}, 24.33 \mathrm{ppm}$ and $12.93 \mathrm{ppm}$ ) (Tab. 2).

The fresh consumed part, aril of pomegranate cultivar revealed that $\mathrm{P}, \mathrm{K}, \mathrm{Mg}, \mathrm{Mn}, \mathrm{Zn}, \mathrm{Cu}, \mathrm{Ca}$ and $\mathrm{Na}$ were the highest at immature stages $(0.44 \%, 1.34 \%, 0.09 \%, 70.60$ ppm, $58.60 \mathrm{ppm}, 27.00 \mathrm{ppm}, 0.16 \%$ and $0.06 \%$,), respectively. Fe was the highest at full mature stages of fruits (Tab. 2).

Comparing unripe and full ripe stages for seed and juice; $\mathrm{K}, \mathrm{Mg}, \mathrm{Mn}, \mathrm{Zn}$ and $\mathrm{Cu}$ were the highest at unripe stage while $\mathrm{Fe}, \mathrm{P}$ and $\mathrm{Ca}$ were the highest at full mature stage for seed. Considerable variations were observed between two development stages in particulaer on Fe and $\mathrm{Mn}$ in seed, For juice $\mathrm{P}, \mathrm{Ca}, \mathrm{Mg}$ and $\mathrm{Na}$ were similar in both stages and $\mathrm{K}$ and Fe were the highest full mature stages and $\mathrm{Mn}, \mathrm{Zn}$ and $\mathrm{Cu}$ were the highest at unripe stage (Tab. 2).

Overall, the potassium was the major element present in the skin, aril, seed and juice of mature development stage of pomegranate cv. 'Hicaznar'. In general the minerals followed in descending order by quantity, $\mathrm{K}>\mathrm{P}>\mathrm{Ca}>\mathrm{Mg}>\mathrm{Na}>\mathrm{Mn}>\mathrm{Zn}>\mathrm{Fe}>\mathrm{Cu}$ with exceptions of Ca was higher than $\mathrm{P}$ in skin (Tab. 2)

Kazankaya et al. (2003) reported P between 72-301 ppm, $\mathrm{K}$ between $856-4423 \mathrm{ppm}, \mathrm{Na}$ between $22-93 \mathrm{ppm}$, Ca between 36-75 ppm, Mg between 50-98 ppm, Fe between 1.2-9.2 ppm, $\mathrm{Zn}$ between 1.8-9.6 ppm, Mn between 0.1-2.9 ppm and $\mathrm{Cu}$ between 0.5-4.2 ppm, respectively which in accordance with our results. Al-Maiman and Ahmad (2002) indicated that arils of pomegranate are rich for $\mathrm{K}, \mathrm{Na}, \mathrm{Mg}$ and $\mathrm{Ca}$, seeds are rich for $\mathrm{Cu}, \mathrm{Zn}$, $\mathrm{Ca}$ and juice are rich for $\mathrm{K}, \mathrm{Na}$ and $\mathrm{Fe}$ which in agreement with our results. Dumlu and Gurkan (2007) studied juice of 12 pomegranate cultivars in Turkey and they found that $\mathrm{K}$ were between 250-1200 ppm, Ca between 35-326 ppm, Mg between 176-427 ppm, Fe between 21$46 \mathrm{ppm}$ and P between 12-43 ppm. In another study, it was found that the concentration of minerals in skin and 
244

Tab. 2. Mineral element contents of pomegranate fruit in different development stages

\begin{tabular}{|c|c|c|c|c|c|}
\hline \multirow{2}{*}{ Minerals } & \multirow{2}{*}{$\begin{array}{c}\text { Development } \\
\text { Stages }\end{array}$} & \multicolumn{4}{|c|}{ Parts of fruit } \\
\hline & & Skin & Aril & Seed & Juice \\
\hline \multirow{3}{*}{$\begin{array}{l}\mathrm{P} \\
(\%)\end{array}$} & Immature fruit & $0.15^{\mathrm{NS}}$ & $0.44 a$ & - & - \\
\hline & Unripe fruit & 0.33 & $0.27 \mathrm{~b}$ & 0.27 & 0.02 \\
\hline & Mature fruit & 0.09 & $0.19 \mathrm{~b}$ & 0.30 & 0.02 \\
\hline \multirow{3}{*}{$\begin{array}{l}\mathrm{K} \\
(\%)\end{array}$} & Immature fruit & $1.22^{\mathrm{NS}}$ & $1.34 \mathrm{a}$ & - & - \\
\hline & Unripe fruit & 1.22 & $0.93 b$ & 0.54 & 0.21 \\
\hline & Mature fruit & 1.10 & $0.88 \mathrm{~b}$ & 0.48 & 1.77 \\
\hline \multirow{3}{*}{$\begin{array}{l}\mathrm{Ca} \\
(\%)\end{array}$} & Immature fruit & $0.29 \mathrm{ab}$ & $0.16 a$ & - & - \\
\hline & Unripe fruit & $0.22 b$ & $0.06 \mathrm{~b}$ & 0.06 & 0.01 \\
\hline & Mature fruit & $0.34 a$ & $0.01 \mathrm{c}$ & 0.18 & 0.01 \\
\hline \multirow{3}{*}{$\begin{array}{l}\mathrm{Mg} \\
(\%)\end{array}$} & Immature fruit & $0.08 \mathrm{a}$ & $0.09 \mathrm{a}$ & - & - \\
\hline & Unripe fruit & $0.05 \mathrm{~b}$ & $0.08 \mathrm{a}$ & 0.08 & 0.01 \\
\hline & Mature fruit & $0.05 b$ & $0.03 b$ & 0.06 & 0.01 \\
\hline \multirow{3}{*}{$\begin{array}{l}\mathrm{Na} \\
(\%)\end{array}$} & Immature fruit & $0.02^{\mathrm{NS}}$ & $0.04 a$ & - & - \\
\hline & Unripe fruit & 0.02 & $0.01 \mathrm{~b}$ & 0.01 & 0.01 \\
\hline & Mature fruit & 0.02 & $0.02 b$ & 0.01 & 0.01 \\
\hline \multirow{3}{*}{$\begin{array}{c}\mathrm{Fe} \\
(\mathrm{ppm})\end{array}$} & Immature fruit & $8.67 \mathrm{~b}$ & $17.67 \mathrm{~b}$ & - & - \\
\hline & Unripe fruit & $5.33 b$ & $11.33 b$ & 12.67 & 0.87 \\
\hline & Mature fruit & $28.07 \mathrm{a}$ & $30.93 a$ & 60.47 & 1.90 \\
\hline \multirow{3}{*}{$\begin{array}{c}\mathrm{Mn} \\
(\mathrm{ppm})\end{array}$} & Immature fruit & $31.33 \mathrm{a}$ & $70.60 \mathrm{a}$ & - & - \\
\hline & Unripe fruit & $30.33 \mathrm{a}$ & $50.87 \mathrm{~b}$ & 57.67 & 7.51 \\
\hline & Mature fruit & $3.87 \mathrm{~b}$ & $4.27 \mathrm{c}$ & 9.73 & 0.30 \\
\hline \multirow{3}{*}{$\begin{array}{c}\mathrm{Zn} \\
(\mathrm{ppm})\end{array}$} & Immature fruit & $24.33 a$ & $58.60 \mathrm{a}$ & - & - \\
\hline & Unripe fruit & $13.33 \mathrm{~b}$ & $42.13 b$ & 37.07 & 5.99 \\
\hline & Mature fruit & $13.07 \mathrm{~b}$ & $22.00 \mathrm{c}$ & 36.67 & 3.40 \\
\hline \multirow{3}{*}{$\begin{array}{c}\mathrm{Cu} \\
(\mathrm{ppm})\end{array}$} & Immature fruit & $12.93 \mathrm{a}$ & $27.00 \mathrm{a}$ & - & - \\
\hline & Unripe fruit & $11.67 \mathrm{a}$ & $24.13 a$ & 25.08 & 2.21 \\
\hline & Mature fruit & $6.87 \mathrm{~b}$ & $11.53 \mathrm{~b}$ & 22.13 & 0.75 \\
\hline
\end{tabular}

Values in the same column with different lettersare significantly at $\mathrm{P}<0.05$. NS: Non significant

aril in pomegranate cultivars were in descending order by quantity of $\mathrm{K}>\mathrm{Ca}>\mathrm{P}>\mathrm{Mg}>\mathrm{Na}>\mathrm{Fe}>\mathrm{Zn}>\mathrm{Cu}>\mathrm{Mn}$ (Mirdehgan and Rahemi, 2007) which supports our findings. In general the minerals were concentrated in the aril than in the juice. As a conclusion, we found a big variation on physico-chemical and mineral content of pomegranate fruit parts as well different deveolepment stages. These variation could be useful for determining product external and internal quality. The result of mineral analysis showed that $100 \mathrm{~g}$ of the samples of the aril and juice of pomegranate cv. 'Hicaznar' would provide more than Recommended Dietary Allowance (RDA) value for adult of nearly all searched minerals.

\section{Acknowledgements}

This study was supported by the Scientific Research Projects Coordination Unit of Akdeniz University.

\section{References}

Al-Maiman SA, Ahmad D (2002). Changes in physical and chemical properties during pomegranate (Punica granatum L.) fruit maturation. Food Chem 76:437-441.

Al-Said FA, Opara LU, Al-Yahyali RA (2009). Physico-chemical and textural quality attributes of pomegranate cultivars (Punica granatum L.) grown in the Sultanate of Oman. J Food Eng 90:129-134.

Alsafwah S, Laguardia SP, Arroyo M, Dockery BK, Bhattacharya SK, Ahokas RA, Newman KP (2007). Congestive heart failure is a systemic illness: a role for minerals and micronutrients. Clin Med Res 5:238-243.

AOAC (1995). Officials methods of analysis ( $16^{\text {th }}$ ed.).VA, USA: Association of Official Analytical Chemist, Arlington.

Avioli LV (1988). Calcium and phosphorus, p. 142-158. In: Shils ME and Young E (Eds.). Modern nutrition in health and disease, $7^{\text {th }}$ Edn. Le and Febiger, Philadelphia.

Celik A, Ercisli S (2009). Some physical properties of pomegranate cv. 'Eksinar'. Int. Agrophysics 23(3):295-298

Cristosto CH, Mitcham EJ, Kader AA (2000). Pomegranate: recommendations for maintaining postharvest quality. Produce Facts. Postharvest Research and Information Centre, University of California, Davis, USA.

El-Nemr SE, Ismail IA, Ragab M (1990). Chemical composition of juice and seeds of pomegranate fruit. Die Nahrung 34:601-606.

Ercan N, Ozvardar S, Gonulsen N, Baldiran E, Onal K, Karabiyik N (1992). Determination of suitable pomegranate cultivars for Aegean region. Proceedings of 1 st National Horticultural Congress. 13-16 October 1992, Izmir-Turkey (in Turkish).

Ercisli S, Esitken A (2004). Fruit characteristics of native rose hip (Rosa spp.) selections from the Erzurum province of Turkey. New Zeal J Crop Hort 32:51-53.

Ercisli S, Agar G, Orhan E, Yildirim N, Hizarci Y (2007). Interspecific variability of RAPD and fatty acid composition of some pomegranate cultivars (Punica granatum $\mathrm{L}$.) growing in Southern Anatolia Region in Turkey. Biochem Syst Ecol 35:764-769.

Ercisli S, Esitken A, Orhan E (2007). Pomegranate genetic resources from northeastern part of Turkey. http://www2. bioversityinternational.org/Regions/Europe/Luxembourg Workshop/Luxembourg\%20files/Posters/Turkey.pdf.

Gates E, Lehmann J (1968) Mineral composition of fruits. J Am Diet Assoc 52:225-231.

Hamilton BK, Yoo KS, Pike LM (1998). Changes in pungency of onions by soil type, sulphur nutrition and bulb maturity. Sci Hortic 74:249-256.

Kazankaya A, Gundogdu M, Askin MA, Muradoglu F (2003). Fruit attributes of local pomegranates grown in Pervari. Proceedings of 4th National Horticultural Congress. 8-12 September 2003, Antalya-Turkey (in Turkish).

Kodia AA, Irigaray JL, Dejou J (1979) Recherche analytique de Élémentsmayeursetd'óligoélémentsdansthebanane,l'avocat, l'ignane et l'attiéké de Côte d'Ivoire, par radioactivation avec des neutrones de $14 \mathrm{Mev}$. Fruits 34:131-134 
Mahan KL, Escott-Stump S (2005). Krause's Food, Nutrition \& Diet Therapy, Philadelphia: Saunders, No. 12, p. 13520.

Mirdehghan SH, Rahemi M (2007). Seasonal changes of mineral nutrients and phenolics in pomegranate (Punica granatum L.) fruit. Sci Hortic 111:120-127.

Onur C, Kaska N (1985). Selection of pomegranates (Punica granatum L.) grown in Mediterranean region of Turkey. T J Agric Forest 9:25-33.

Ozkan Y (2005). Investigations on physical and chemical characteristics of some pomegranate genotypes (Punica granatum L.) of Tokat province in Turkey. Asian J Chem 17:939-942.

Pellerano RG, Mazza SS, Marigliano RA, Marchevsky EJ (2008). Multielement analysis of Argentinean lemon juices by instrumental neutronic activation analysis and their classification according to geographical origin. J Agric Food Chem 56:5222-5225.

Polat AA, Durgac C, Kamiloglu O, Mansuroglu M, Ozturk G. (1999). Studies on determination of pomological characteristics of some pomegranate types grown in Kirikhan district of Hatay province. Proceedings of $3^{\text {nd }}$ National Horticultural Congress. 14-17 September 1999, AnkaraTurkey (in Turkish).

Poyrazoglu E, Gokmen V, Artik N (2002). Organic acids and phenolic compounds in pomegranates (Punica granatum L.) grown in Turkey. J Food Comp Anal 15:567-575.
SAS Institute (2005). SAS Online Doc., Version 8. SAS Inst., Cary, NC, USA.

Tibet H, Onur C (1999). Adaptation of pomegranate (Punica granatum L.) cultivars in Antalya region. Proceedings of 3th National Horticultural Congress. 14-17 September 1999, Ankara-Turkey (in Turkish).

Viuda-Martos M, Fernandez-Lopez J, Perez-Alvarez JA (2010). Pomegranate and its many functional components as related to human health: A Review. Comp Rev Food Sci Food Safety 9:635-654.

Williams M (2006). Dietary supplements and sports performance: metabolites, constituents, and extracts. J Int Soc Sports Nutr 3:1-5.

Yildiz K, Muradoglu F, Oguz HI, Yilmaz H (2003). Pomological characteristic of pomegranate varieties grown in Hizan town of Bitlis. Proceedings of $4^{\text {th }}$ National Horticultural Congress. 8-12 September 2003, Antalya-Turkey (in Turkish).

Yilmaz H, Sen B, Yildiz A (1992). Regional adaptation of pomegranates selected from Mediterranean region. Proceedings of $1^{\text {st }}$ National Horticultural Congress. 13-16 October 1992, Izmir-Turkey (in Turkish). 